Original Research Paper

\title{
Peningkatan Kemampuan Mengembangkan Pembelajaran Menggunakan Alat Peraga Menentukan Luas Daerah Bidang Rata Bagi Guru SD di Gugus III Kecamatan Kediri
}

\author{
Ketut Sarjana $^{1 *}$, Muhammad Turmuzi ${ }^{1}$, Sahrul Azmi ${ }^{1}$, Ni Made Intan Kertiyani ${ }^{1}$, Wahidaturrahmi ${ }^{1}$ \\ ${ }^{1}$ Program Studi Pendidikan Matematika, FKIP, Universitas Mataram, Mataram, Indonesia
}

\begin{abstract}
https://doi.org/10.29303/jpmpi.v3i2.1173
\end{abstract}
Sitasi: Sarjana, K., Turmuzi, M., Azmi, S., Kertiyani, N. M. I \& Wahidaturrahmi. (2021). Peningkatan Kemampuan Mengembangkan Pembelajaran Menggunakan Alat Peraga Menentukan Luas Daerah Bidang Rata Bagi Guru SD di Gugus III Kecamatan Kediri. Jurnal Pengabdian Magister Pendidikan IPA 4(4)

\section{Article history}

Received: 02 Oktober 2021

Revised: 20 Oktober 2021

Accepted: 09 November 2021

*Corresponding Author: Ketut Sarjana, Program Studi

Pendidikan Matematika, FKIP, Universitas Mataram, Mataram, Indonesia

Email:

kssarjanafkip@gmail.com

\begin{abstract}
Para guru SD di Kecamatan Kediri belum pernah merancang pengembangan pembelajaran menggunakan alat peraga menentukan luas daerah bangun datar Jadi masalah yang muncul adalah para guru gugus III di Kecamatan Kediri kemampuan mengembangkan pembelajaran menggunakan alat peraga menentukan luas daerah bangun datar masih rendah. Tujuan yang ingin dicapai dalam kegiatan pengabdian ini adalah: 1) Meningkatkan kemampaun para guru SD Gugus III di Kecamatan Kediri tentang merancang alat peraga menentukan luas daerah bangun datar dan 2) Meningkatkan kemampuan merancang langkahlangkah pembelajaran menggunakan alat peraga menetukan luas daerah bangun datar. Permasalahan yang dialami oleh para guru terkait dengan merancang pengembangan pembelajaran menggunakan alat peraga dapat diselesaikan dengan:1) Memberikan pemahaman tentang merancanag alat peraga menentukan luas daerah bangun datar, 2) Simulasi dan praktek merancang pengembangan pembelajaran menggunakan alat peraga menentukan luas daerah dan 3) Diskusi dalam kelompok kerja dan presentasi tentang hasil kontruksi alat peraga dan langka-langkah pengembangannya. Kegiatan Pengabdian kepada masyarakat telah dilakukan melalui metode yang telah ditatapkan. Hasil dari kegiatan ini ternyata sangat efektif yakni terjadi perubahan kearah perbaikan yang signifikan hal ini ditunjukkan oleh skor rata-rata pre-tes $=4,138$ lebih kecil dari skor ratarata post-tes $=7,320$. Dari hasil uji diperoleh $t_{h}=18,772>t_{\operatorname{tab}}=1,725$ pada tafar signifikasi 0.05 . Jadi secara keseluruhan bahwa pengetahuan tentang luas daerah bangun datar dan keterampilan merancang pengebangan pembelajaran menggunakan alat peraga menentukan luas daerah bidang rata para guru SD di Gugus III Kecamatan Kediri meningkat yang ditunjukkan oleh perubahan nilai rerata tersebut. Dengan diperolehnya hasil dari kegiatan ini diharapkan pelatihan ini diperluas dalam rangka memperkuat pelaksanaan kurikulum 2013 dan para pemerhati pendidikan turut serta mengambil peran untuk mewujudkan kegiatan ini untuk mengantisipasi pembelajaran matematika abad 21.
\end{abstract}

Keywords: Kemampuan mengembangkan masalah, alat peraga, luas daerah bidang datar, Kediri

\section{Pendahuluan}

Keberadaan matemtika seperti geometri sangatlah abstrak hal ini diungkap oleh Ruseffendi (1998) menyebut bahwa matematika merupakan suatu ilmu yang berhubungan dengan penelahan bentuk-bentuk atau struktur-struktur yang abstrak dan hubungan diantara hal itu. Untuk dapat memahami struktur-struktut dan hubunganhubungan itu diperlukan pemahaman tentang konsepkonsep, prinsip di dalam matematika. 
Disisi lain Piaget dalam Hudoyo mengidentifikasi bahwa siswa sekolah dasar berpikirnya masih pada tahap operasi kongkret (Hudoyo, 2008). Itulah sebabnya siswa belajar geometri sangat sulit seperti diungkap dalam hasil survei Program for international Student Asseement 2000/2001 menyatakan bahwa siswa lemah dalam geometri khususnya dalam ruang dan bentuk (Suwaji, 2008).

Siswa sekolah dasar belajar konsep atau prinsip geometri sebaiknya dihadapkan dengan obyek atau benda yang kongkrit yang cocok. Selanjutnya obyek kongkrit ini dimanipulasi oleh anak untuk membangun konsep atau prinsip geometri yang sedang dipelajari. Hal ini sesuai dengan pernyataannya Brunner dalam Nyimas Aisyah menyebut bahwa dalam proses belajar anak sebaiknya diberi kesempatan memanipulasi bendabenda yang dirancang secara khusus dan dapat diotak atik oleh siswa di dalam memahami konsep matematika (Aisyah: 2007). Supaya obyek matematika yang dirancang khusus dan dapat diotak atik biasanya berupa alat peraga.

Siswa belajar mengunakan alat berarti siwa berbuat untuk memperoleh konsep yang sedang dipelajari. Dengan berbuat fakta, konsep dan prinsip yang terbangun akan mengendap dalam memori anak lebih lama. Belajar dengan cara berbuat sesuai dengan motto cina yang dikutip oleh Ruseffendi yang mengatakan bahwa saya mendengar maka saya lupa, saya melihat maka saya tahu, saya berbuat maka saya mengerti (Ruseffendi:1998).

Membelajarkan tentang pengukuran luas suatu bangun datar supaya bisa diotak atik dapat dilakukan dengan cara memotong bangun tersebut menjadi beberapa potongan sedemikian rupa supaya terbentuk bangun yang lain. Bangun yang lain ini biasanya bangun yang telah dikenal betul oleh siswa. Jadi disini kita sebenarnya berbicara konsep kekelan luas. Seperti yang diungkap oleh Ruseffendi mengatakan kekelan luas menyebutkan bahwa luas daerah suatu bangun datar tidak akan berubah walaupun dipotong-potong menjadi bangun-bangun lain. Dalam pengembangan langkah-langkah pembelajaran disini akan memanfaatkan konsep kekelan luas. Misalnya menetukan luas daerah segitiga dilakukan dengan cara memotong daerah segitiga menjadi bebrapa potongan kemudian diubah menjadi daerah persegi panjang. Selanjutnya menentukan hubungan unsurunsur segitiga dengan unsur-unsur persegi panjang. Hal ini dilakukan karena konsep persegipanjang dipandang sebagai prasyarat pegetahuan untuk mengajarkan segitiga. Dalam hal ini dapat disebutkan bahwa menentukan luas daerah segitiga dengan pendekatan luas daerah persegi panjang

Penggunaan alat peraga akan optimal jika pengembangannya di kelas tepat. Untuk itu diperlukan suatu langkah langkah pembelajarannya agar sesuai dengan tujuan yang diharapkan. Langkah langkah tersebut tentu didasari oleh teori belajar. Khususnya tentang geometri erat kaitannya dengan teori belajar Van Hiele.

Menurut Van Hiele dalam Suherman dan Winataputra, (1993) terdapat 5 tahap belajar siswa di dalam belajar Geometri yaitu :

1. Tahap pengenalan : dalam tahap ini anak mulai belajar mengenali suatu bentuk geometrin secara keseluruhan, namun belum mapu mengetahui adanya sifat-sifat dari bentuk yang diamati.

2. Tahap Analisis : disisni siswa sudah mulai mengenal sifat-sifat yang dimiliki benda geometri yang diamatinya.

3. Tahap pengurutan : disini siswa sudah mampu melaksanakan penarikan kesimpulan yang dikebal dengan berpikir deduktif tetapi belum berkembang secara penuh.

4. Tahap deduksi : pada tahap ini siswa sudah mampu menarik kesimpulan secara deduktif yakni penarikan kesimpulan yang bersifat umum menuju hal yang bersifat khusus.

5. Tahap akurasi : pada tahap ini siswa sudah menyadari betapa pentingnya ketepatan dari prinsip dasar yang melandasi suatu pembuktian.

Ketika prinsip geometri tentang luas daerah telah terbangun pada diri anak sebaik nya diperkuat dengan cara memberikan latihan- latihan Hal ini sejalan dengan teori Thorndike dalam Ruseffendi (1992) yaitu hukum latihan yang menyatakan bahwa jika hubungan stimulus-respon sering terjadi akibatnya hubungan itu semakin kuat, sedangkan makin jarang hubungan stimulus - respon dipergunakan makin melemah-nya hubungan tersebut.

Pembelajaran yang dikolaborasikan dengan pemanfaatan alat peraga dan alat bantu 
pembelajaran akan menjadi strategi pembelajaran yang efektif dan dapat diterima oleh siswa. Disamping itu sudah banyak tulisan yang menyebut bahwa penggunaan alat peraga dalam pembelajaran matematika menyebabkan pempelajaran menjadi efektif. Salah satu yang diungkap oleh Brown (1970) dalam Asra menyebut bahwa media yang digunakan siswa atau guru dengan baik dapat mempengaruhi efektifitas proses belajar dan mengajar. Namun dalam tulisan tersebut belum menyebut bahwa bagaimana langkah-langkah pembelajarannya supaya alat yang digunakan menjadi efektif.

Pada kenyataannya para guru sekolah dasar jika menggunakan alat peraga dalam pembelajaran geometri hasilnya berbeda satu dengan yang lainnya walaupun alat peraga yang digunakan sama untuk materi yang sama dan pada tingkatan yang sama.

Ini berarti bahwa para guru dalam mengajar geometri dengan menggunakan alat peraga membutuhkan kemampuan mengembangkan pembelajarannya agar alat peraga yang digunakan menjadi efektif.

\section{Metode}

Seperti apa yang terungkap pada bab sebelumnya bahwa tujuan dari kegiatan pengabdian ini adalah merancang alat peraga dan angkahlangkah pembelajaran menggunakan alat peraga menetukan luas daerah bangun datar.

Untuk mencapai tujuan ini ada berapa kegiatan yang harus dilakukan yakni :

1. Memberikan pemahaman merancang alat peraga menentukan luas daerah bangun datar.

Sebelum pendalaman materi para guru diberikan pre-test yang berisikan tentang bagaimana rancangan membangun rumus luas daerah bangun datar. Pemahaman tentang hubungan antar unsur dari akibat kekelan luas daerah. Dari hubungan itu dapat dibentuk bangun-bangun lain berdasarkan bangun daerah persegi panjang. Seperti halnya bangun Jajaran genjang, Segitiga, trapezium, layang-layang , daerah lingkaran dapat dibentuk melalui pendekatan daerah persegi panjang. Pendalaman materi disini dimulai dari bagaimana suatu daerah memiliki luas daerah yang sama akibat kekekalan luas. Bagaimana cara mengkontruksi potongan daerah menjadi daerah persegi panjang.

2. Praktek dan simulasi.

Pada kegiatan praktek disini para guru membuat daerah bangun datar, seperti daerah persegi panjang, jajaran genjang, segitiga, trapezium, layang-layang, belah ketupat dan daerah lingkaran dari karton atau kertas manila yang telah disiapkan. Selanjutnya daerah bangun datar yang dibuat dipotong-potong menjadi beberapa daerah tertentu. Selanjutnya simulasi membuat potongan yang terjadi dirangkai menjadi daerah persegi panjang. Karena menentukan rumus luas daerah didekati dari luas darah persegi panjang dan hukum kekekalan luas. Hasil simulasi ditempelkan pada stereoform yang telah disediakan. Selanjutnya didemonstrasikan salah satu alat peraga yang telah dibuat.

Dari rancangan yang sudah disepakati dibuatkan langka-langkah pembelajarannya supaya alat yang dirancang bermanfaat secara optimal. Langkah-langkah pengembangan dimulai dari menggali prasyarat, merangkai bangun datar, membuat perhitungan dan membuat hubungan antara besaran yang diperoleh dan membuat kesimpulan.

3. Diskusi dan Presentasi.

Peserta pengabdian dibagi menjadi 5 kelompok kerja. Tiap kelompok mengerjakan tugas yang berbeda. Hasil pekerjaan didiskusikan dan disimulasikan pada tiap kelompok. Pekerjaan menyangkut tentang merancang alat peraga dan petunjuknya. Selanjutnya pekerjaan tiap kelompok dipresentasikan pada kelompok besar untuk mendapatkan tanggapan dari peserta kelompok yang lain dan penegasan dari tim pengabdian.

4. Untuk mengetahui efektifitas kegiatan data yang diperoleh dianalisis menggunakan uji $t$ yakni dengan rumus

$t=\frac{\bar{d}}{s_{d} / \sqrt{n}}$ 


\section{Hasil dan Pembahasan}

\section{Data Hasil Pengabdian pada Masyarakat.}

Sebelum dilakukan pelatihan peserta diberikan pretes yang memuat 10 butir soal yang terdiri dari pengetahuan tentang unsur unsur dari Tabel penolong berikut untuk mencari nilai $\bar{d}$ bangun datar, luas daerah dan keterampilan menyusun kalimat langkah-langkah pengembangan di depan kelas menggunakan alat peraga. Mengenai hasil tes dapat dilihat pada Tabel 1 . .

\begin{tabular}{|c|c|c|c|c|}
\hline \multirow{2}{*}{ No. } & \multirow{2}{*}{ Nama peserta } & \multicolumn{2}{|c|}{ Skor } & \multirow{2}{*}{ Beda (post-pre) } \\
\hline & & Pretes & Postes & \\
\hline 1 & Maimunah, S.Pd & 5 & 7 & 2 \\
\hline 2 & Sapiah, S.Pd & 5 & 8 & 3 \\
\hline 3 & Eka Oktapiani, S.Pd & 4 & 8 & 4 \\
\hline 4 & Nurhasanah, S.Pd & 5 & 7 & 2 \\
\hline 5 & Agung Kurnianto, S.Pd.Sd & 2 & 6 & 4 \\
\hline 6 & Nurdin, S.Pd & 5 & 7 & 2 \\
\hline 7 & Mustofa Halil, S.Pd & 4 & 7 & 3 \\
\hline 8 & Sibawaihi, S.Pd & 5 & 8 & 3 \\
\hline 9 & Hj Ratminah, S.Pd & 4 & 7 & 3 \\
\hline 10 & Jauhariah & 5 & 8 & 3 \\
\hline 11 & Misnawati & 3 & 6 & 3 \\
\hline 12 & Munawarah & 4 & 7 & 3 \\
\hline 13 & Ruswati, S.Pd & 4 & 8 & 4 \\
\hline 14 & Ismiyatun, S.Pd & 5 & 8 & 3 \\
\hline 15 & Rauhun, S.Pd & 4 & 7 & 3 \\
\hline 16 & Faizah, S.Pd & 4 & 7 & 3 \\
\hline 17 & Irma Puspa, S.Pd & 5 & 7 & 2 \\
\hline 18 & Yuli Suryani, S.Pd & 3 & 7 & 4 \\
\hline 19 & Bambang Rudianto, S.Pd & 3 & 8 & 5 \\
\hline 20 & Eriansyah, S.Pd & 4 & 8 & 4 \\
\hline 21 & Ahmad Turmuzi, S.Pd & 4 & 7 & 3 \\
\hline 22 & Azwar Anas & 4 & 8 & 4 \\
\hline & Rata-rata & 4,138 & 7,320 & $\bar{d}=3.182$ \\
\hline & $\begin{array}{c}\text { standar dev } \\
\mathrm{d}\end{array}$ & & & 0.795 \\
\hline
\end{tabular}

Sehingga diperoleh nilai t-hitung sebagai berikut.

$t=\frac{\bar{d}}{s_{d} / \sqrt{n}}=\frac{3,182}{0,795 / \sqrt{22}}=18,772$

Selanjutnya nilai t-hitung tersebut dibandingkan dengan nilai t-tabel, dengan $d k=22-2=20$ dan $\alpha=0,05$ uji satu sisi, sehingga nilai t-tabel $=1,725$.
Karena $\mathrm{t}_{\text {hitung }}=18,772>\mathrm{t}_{\text {tabel }}=1,725$ maka hipotesis nol ditolak, dengan kata lain nilai post-test lebih besar daripada nilai pre-test.

Pelaksanaan kegiatan Pengabdian pada masyarakat dilaksanakan di pusat Gugus III di SD No.1. Rumak Kecamatan Kediri . Kegiatan dilaksanakan sebagai berikut :

1. Pendalaman materi.

Sebelum pendalaman materi para guru diberikan pre-test yang berisikan 
tentang pengertian luas daerah dan bagaimana mengaktualisasikan kedalam daerah persegi panjang, jajaran genjang, segitiga, trapezium, layamg-layang, daerah ling-karan. Pendalaman materi disini dimulai dari pembahasan luas daerah, menyampaikan cara-cara mengkontruksi medianya melalui pendekatan luas daerah persegi panjang. Pemberian tes ini dimaksudkan untuk memperoleh pengetahuan dan keterampilan awal peserta.
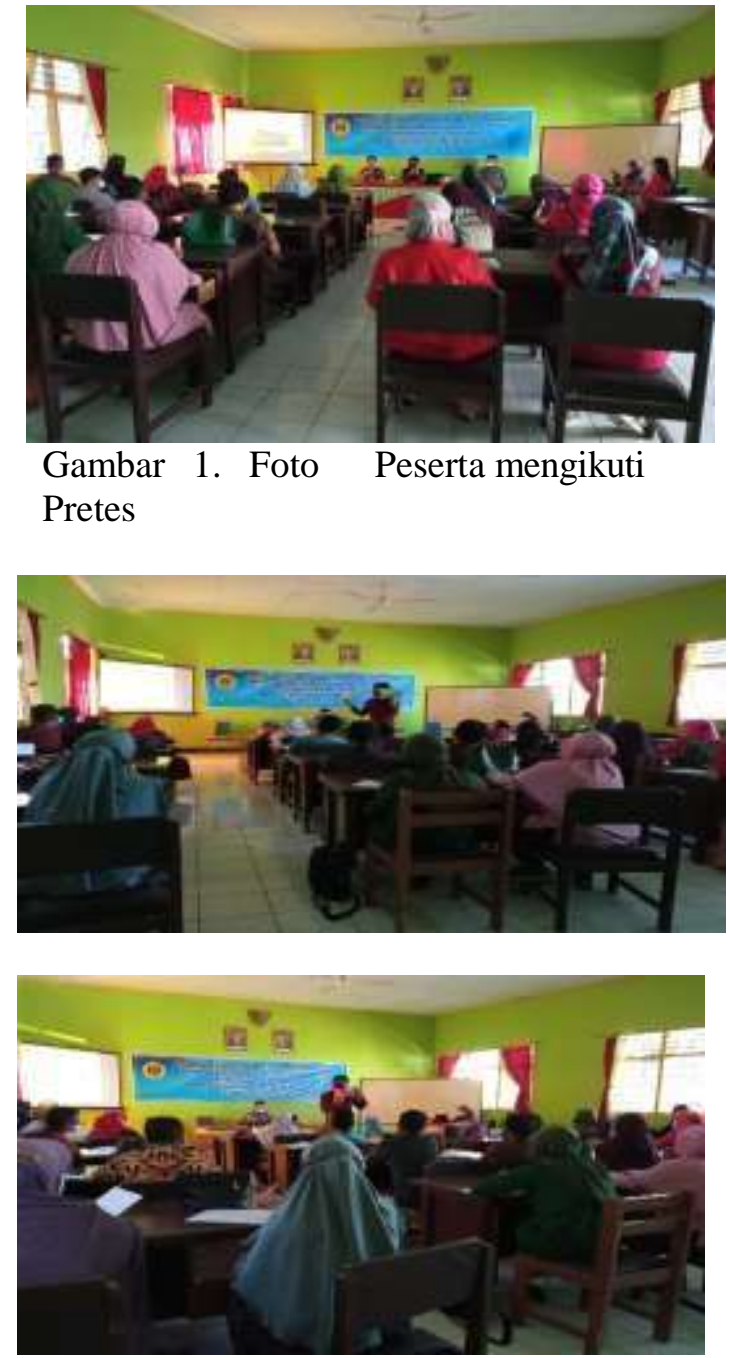

Gambar 2. Foto Pendalaman Materi Pengabdian

2. Praktek dan simulasi.

Pada kegiatan praktek disini para guru membuat daerah bangun datar dari karton atau kertas manila yang telah disiapkan. Para peserta disebar ke dalam 5 kelompok kerja yang masingmasing bekerja menentukan rumus luas daerah. Ada 5 daerah bangun datar yang dimaksud adalah, jajaran genjang, segitiga, trapesium, layang-layang, dan daerah lingkaran yang akan dicari rumus luasnya. Selanjutnya peserta melakukan simulasi memotong daerah bangun datar menjadi beberapa potongan daerah tertentu. Selanjutnya potongan-potongan yang terjadi dirangkai menjadi daerah persegi panjang. Dilanjutkan membuat pedoman operasional sesuai dengan alat yang telah dikontruksi.

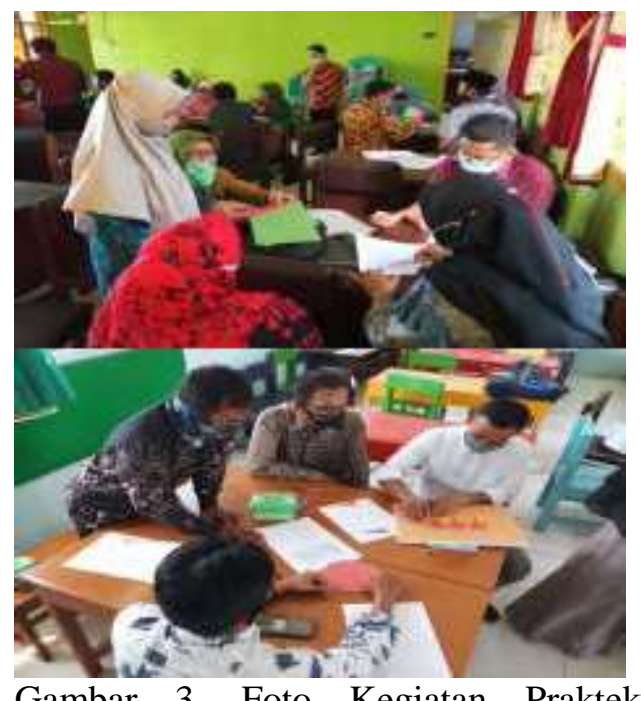

Gambar 3. Foto Kegiatan Praktek merancang alat bahan karton.

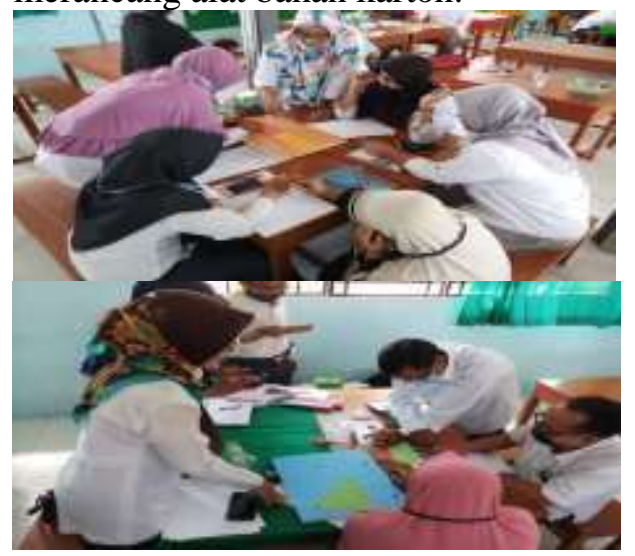

Gambar 4. Foto Kegiatan bersimulai membuat langkah-langkah pengembangan alat peraga luas daerah bangun datar. 


\section{Diskusi dan presentasi.}

Peserta pelatihan dibagi menjadi 5 kelompok kerja. Setiap kelompok mendapatkan tugas sesuai dengan 5 topik bahasan yaitu mengkontruksi petunjuk penggunaan alat peraga bangun datar Jajaran genjang, Segitiga, Trapesium, Layang-layang dan Luas daerah Lingkaran. Di dalam kelompok peserta berdiskusi, merancang alat dengan karton, kemudian membuat langkah-langkah untuk mengembangkan di depan kelas. Langkah-langkah pengembangan dimulai dari menggali prasyarat, merangkai bangun datar, membuat perhitungan dan membuat hubungan antara besaran yang diperoleh dan membuat kesimpulan. Hasil diskusi dipresentasikan dengan cara menempel pada stereoform yang telah disediakan dan langkah pengembangannya disajikan di depan kelas dan kelompok lain menanggapi dan menyempurnakan.

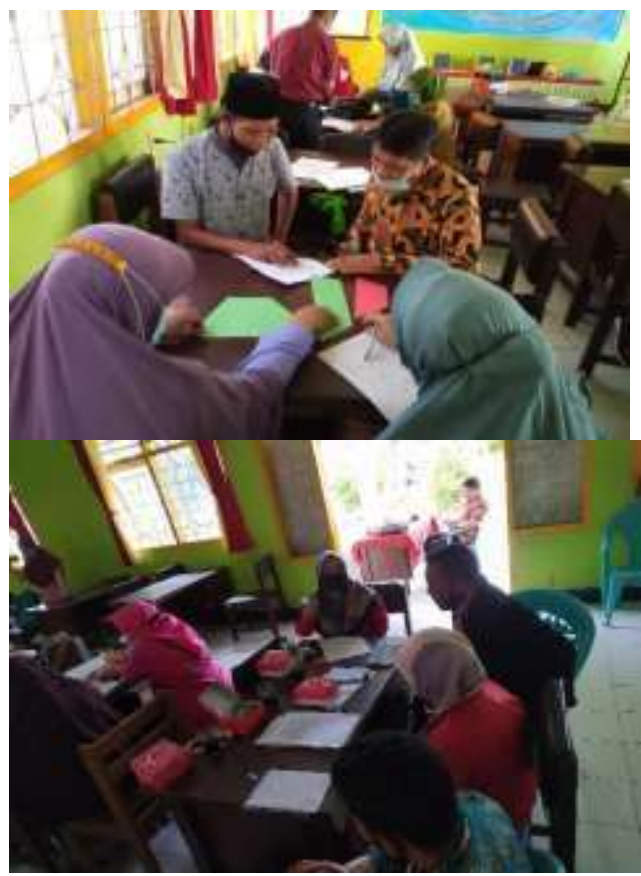

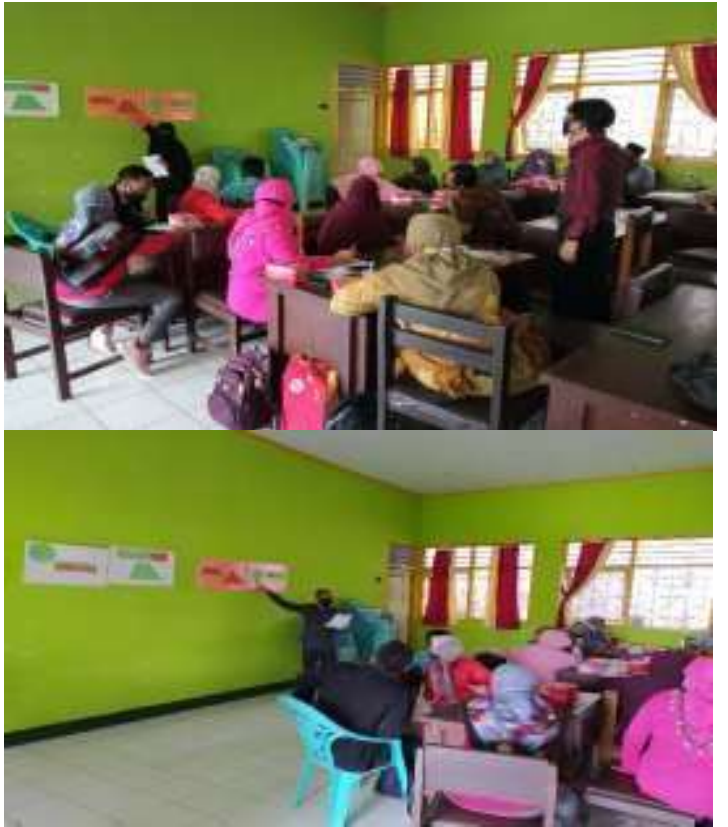

Gambar 5. Foto Kegiatan Diskusi dan Presentasi
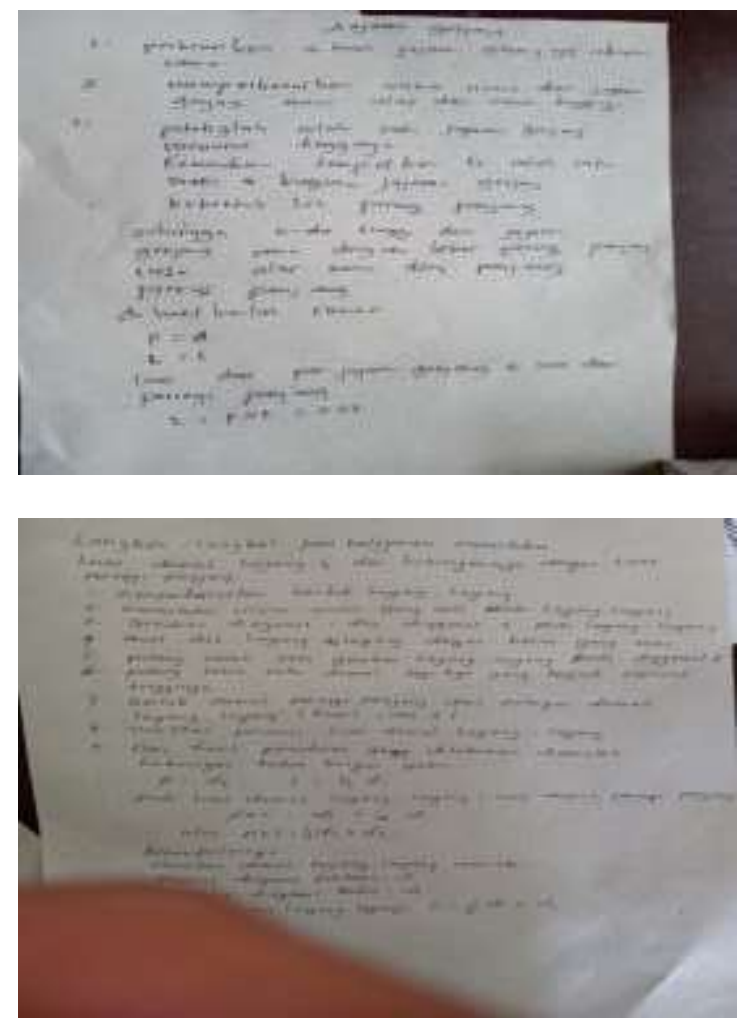


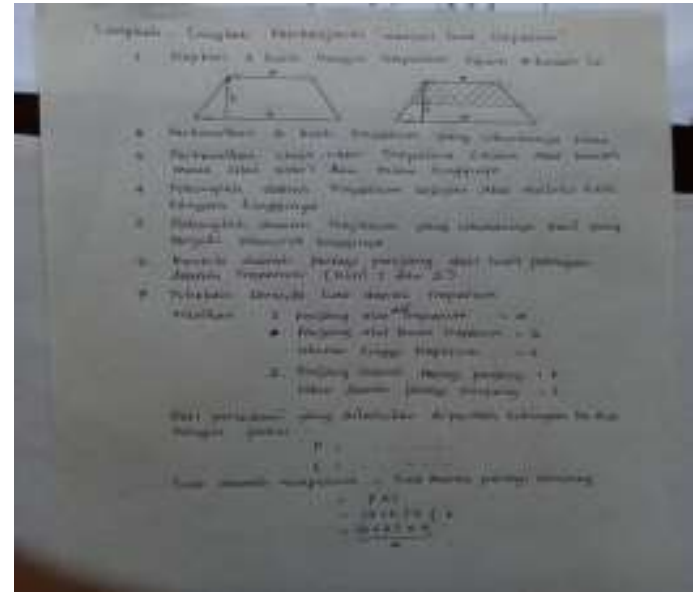

Gambar 6. Foto hasil menyusun cara pengembangkan Alat peraga di kelas.

Para guru mengikuti sangat antausia dan serius, ditunjukkan dengan adanya tanya jawab dalam diskusi, bekerja dalam kelompok. Kemudian presentasi kelompok dan tukar pandangan secara klasikal sampai akhir kegiatan yang ditunjukan pula melalui rekaman dokumentasi.

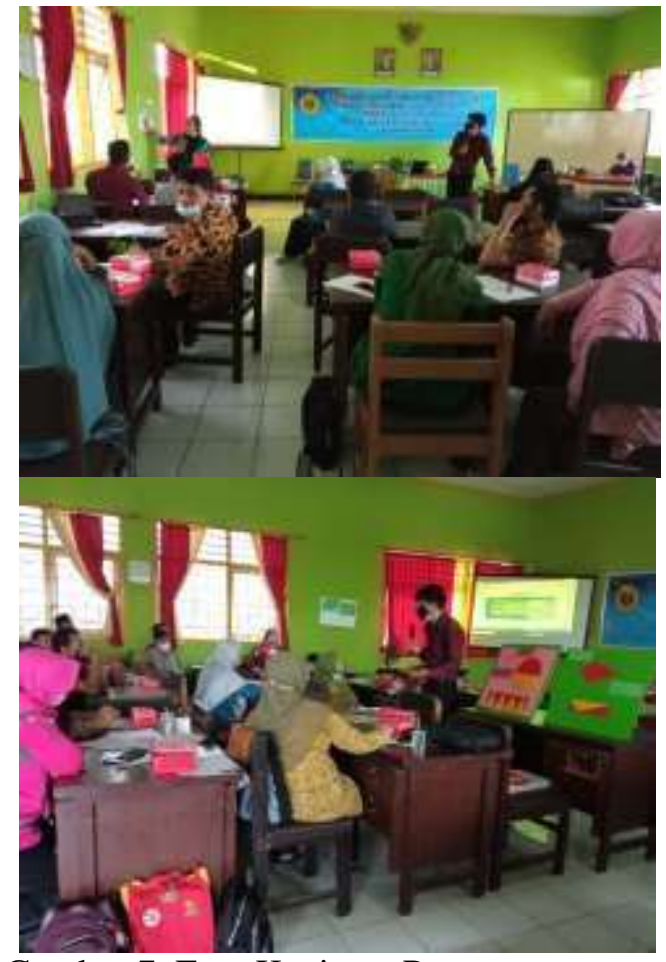

Gambar 7. Foto Kegiatan Penguatan secara Klasikal

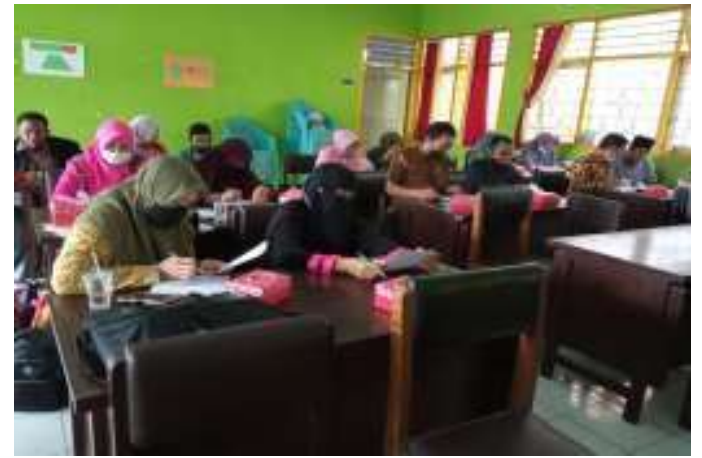

Gambar 8. Foto Pelaksanaan Post- tes.

Setelah kegiatan pengabdian dilakukan para peserta diberikan post-tes. Soal-soal yang dirancang mengilustrsikan persoalan menggali prasyarat pengetahuan tentang bangun datar yang diungkapkan pada soal - soal yang bernomor ganjil dan soal-soal yang bernomor genap mengungkap tentang bagaimana alat itu dikontruksi sampai kepada terbuat pengembangan pembelajarannya di depan kelas. Pada kesempatan yang sama berarti telah terjadi perubahan yang signifikan kearah perbaikan tentang keterampilan para guru SD Gugus III di Kecamatan Kediri setelah mengikuti kegiatan pengabdian ini.

\section{Kesimpulan}

Kegiatan Pengabdian kepada masyarakat telah dilakukan melalui metode yang telah ditatapkan. Hasil dari kegiatan ini ternyata sangat efektif yakni terjadi perubahan kearah perbaikan yang signifikan hal ini ditunjukkan oleh skor ratarata pre-tes $=4,138$ lebih kecil dari skor rata-rata post-tes $=7,320$. Dari hasil uji diperoleh $t_{h}=18,772>t_{t a b}=1,725$ pada tafar signifikasi 0,05 .

\section{Ucapan Terimakasih}

Ucapan terimakasih pada Universitas Mataram telah mendanai kegitan ini melalui dana PNBP UNRAM tahun 2021. 


\section{Daftar Pustaka}

Aisyah, N, dkk. 2007. Pengembangan Pembelajaran Matematika SD. Jakarta : Departemen Pendidikan Nasional.

Asra, D. D., \& Riana, C. (2007). Komputer dan Media Pembelajaran di SD. Dirjen Dikti Departemen Pendidikan Nasioanal. Jakarta.

Brown, R. (1970). Computer-oriented Mathematics: Predicting the Outcome of the World Series. The Mathematics Teacher, 63(6), 494-500.

Hudoyo, H (2008). Pengembangan Kurikulum Matematika di depan Kelas, Usaha Nasional Surabaya.

Marie-Christine Opdenakker, Jan Van Damme. 2006. Teacher Characteristic and Teaching Style Effectiveness Enhancing Factors of Classroom Practice, Teaching and Teacher Education 22 www.Elsevier.com/locate/tate.

Suherman dan Winataputra, (1993) . Strategi Belajar Mengajar Matematika. DEPDIKBUD DirDirjen Dikdasmen Bagian Proyek Penataran Guru SLTP. Jakarta.

Russefendi ET ( 1996). Pendidikan Matematika III Modul 1-9, Depdikbud, Proyek Tenaga Kependidikan, Jakarta.

Sarjana Ketut, Sridana Nyoman, M. Turmuji (2018). Desain Media Peraga dan Bantu Pembe lajaran Geometri bagi siswa Sekolah Dasar Kelas Tinggi, Hasil Penelitian yang dibiayai dari dana PNBP UNRAM 2018.

Suwaji, Untung Trisna. (2008). Permasalahan Pembelajaran Geometri Ruang SMP dan Alternatif pemecahannya. Yogyakarta : P4TK Matematika. 